\title{
Stage I Cutaneous Melanoma AJCC v6
}

National Cancer Institute

\section{Source}

National Cancer Institute. Stage I Cutaneous Melanoma AJCC v6. NCI Thesaurus. Code C7916.

Stage I includes: IA (T1a, N0, M0); IB (T1b, N0, M0); (T2a, N0, M0). T1a: Melanoma is less than or equal to $1.0 \mathrm{~mm}$ in thickness with or without ulceration. T1b: Melanoma is less than or equal to $1.0 \mathrm{~mm}$ in thickness and level IV or V with ulceration. T2a: Melanoma 1.01-2.0 mm in thickness, no ulceration. N0: No regional lymph node metastasis. M0: No distant metastasis.-2003 